\title{
Aabenraa amt og dets økonomi på reformationstiden
}

\author{
af Bjorn Poulsen
}

Amtsregnskaberne er en af de ældste kilder til lokalsamfundets historie. I Aabenraa amts regnskaber fra 1530 'erne kan man lase om Brundlund slot som centrum for datidens lokaladministration og om de mange relationer mellem slottet og det omgivende land. Arkivar Bjørn Poulsen viser, hvordan administrationen på slottet var med til at sætte værdier i cirkulation i amtet.

Sydvest for den lave by med de mange grønne haver stod og står Aabenraa slot, også kaldet Brundlund. Den tilbagetrukne beliggenhed svarer nu om dage til en forholdsvis begrænset funktion i Aabenraaegnens administrative og økonomiske liv. Sådan har det ikke altid været. I den periode, der her skal skildres, svarede de opgaver, der blev løst fra bygningen, nærmest til dem der nu om dage løses af både amtets og amtskommunens omfattende administration.

Man kan altså med god grund interessere sig for, hvilken økonomisk rolle Aabenraa slot spillede for det amt eller len, det var det administrative midtpunkt for ${ }^{\prime}$. Helt generelt er det af betydning for diskussionen af det offentliges plads i tidligere samfund at få fastlagt de strømme af værdier, som den statslige administration førte til og fra lokalsamfundet. Alt for ofte skildres samspillet mellem stat og samfund $i$ ældre tid som en envejs kommunikation, der blot bestod $\mathrm{i}$ overførslen af lokalsamfundets ressourcer til fjerntliggende fyrstepaladser og soldaterlejre. Mere specifikt kan undersøgelser af kilderne fra Aabenraa amt naturligvis give et indblik i lokalsamfundet, som ikke kan nås på anden vis, da amtsregnskaber og andre kilder skabt af amtmændene ofte er de eneste bevarede vidnesbyrd om landområdernes ældre historie.

\section{Kilderne}

De kilder der skal bruges, er de ældste mere omfattende kilder til Aabenraa amts historie.

Der er for det første tale om et inventar for Aabenraa slot fra 30.april 1523, der kan give et indblik i slottets rumfunktioner ${ }^{2}$. Dernæst er der tale om de tidligste regnskaber fra amtet. Disse regnskaber, der tillader en undersøgelse 
han overtog Aabenraa slot dette år. Man kan fornemme, at registreringen må være blevet til under en rundgang $i$ bygningerne med pen og papir ved hånden.

Rundgangen startede fra porthuset nede $\mathrm{i}$ den gamle stue, win dem olden stauen«. Her var et lager for kød og salt. Man fandt 380 sider kød og andet svinekød, 16 tønder frisisk og 16 tønder lyneborg salt, hvoraf en af de sidstnævnte var åbnet og fuld af skidt ("schit«!) samt 2 tønder sild. Her stod imidlertid også våben og møbler. Der var 10 hagebøsser og 4 andre gamle bøsser med krudt hertil, samt 9 senge med puder, dyner og lagner; der var 1 skab, 1 tinkande og 2 bækkener, 1 tinpotte, der var 1 kiste, som den forrige lensmand Benedict von der Wisch endnu havde kappe og pels i; der var en "lowbok « - vel Jyske Lov - skrevet på pergament.

Fra porthuset bevægede man sig til køkkenet, "koken«. Her stod bl.a. 4 kedler, 9 gryder, spid og bradepande, 409 sider kød, 43 svinerygge, saltede svinefødder og hoveder, 1 tønde smør og en tønde ål, lidt talg og honning og noget tørret fisk.

Derefter kom så turen til forrådskammeret, "spiker «, hvor der befandt sig 5 læster 1 ørtug havre, samt adskilligt rug og byg. I tilslutning hertil hører man, at der på slottet, wup dem slott«, lå 1 læst $11 \frac{1}{2}$ ørtug havre. I kælderen, "keller« og bageriet, "backhuse« stod en bryggekedel, 26 tomme tønder og nogle fade samt 1 saltekedel.

Endelig giver inventaret os en vis viden om den ladegård, »ladehaue«, som lå ved borgen. Her stod i stalden 22 køer og 1 tyr. Hertil kom 17 stk. ungkvæg og 1 okse, 4 smågrise og 9 gas. Heste nævnes ikke, men fra det senere kornregnskab fra 1535 kan udledes, at amtmanden havde et antal heste, bl.a. to postheste og en trækhest. Af kornregnskabet ses også, at en del af borgens korn brugtes til opfodring af gas.

Inventaret repræsenterer naturligvis på ingen måde noget højdepunkt $\mathrm{i}$ slottets liv. Barske tider var netop overstået. 22. marts 1523, altså en måned før inventaret blev optegnet, havde hertugens ryttere plyndret Aabenraa by og indtaget borgen, og den afgåede kongelige amtmand havde sikkert taget med sig, hvad han med rimelighed kunne ${ }^{6}$. Kvægbesætningen på ladegården var pæn, men ikke imponerende stor. I de følgende år blev der lagt mere vægt på ladegårdens drift, og antallet af køer var i begyndelsen af 1580 'erne fra de 22 i 1523 vokset til omkring 40 og steg i de følgende år op mod år 1600 yderligere til over $80^{7}$. Alligevel giver oversigten et billede af et hus fyldt med forråd og lagre og optaget af mange aktiviteter. Et sted hvor mange værdier bevægede sig til og fra. De ombygninger af selve slottet, der fandt sted i de følgende år, skulle yderligere forbedre rammerne for amtmandens virke ${ }^{8}$. 


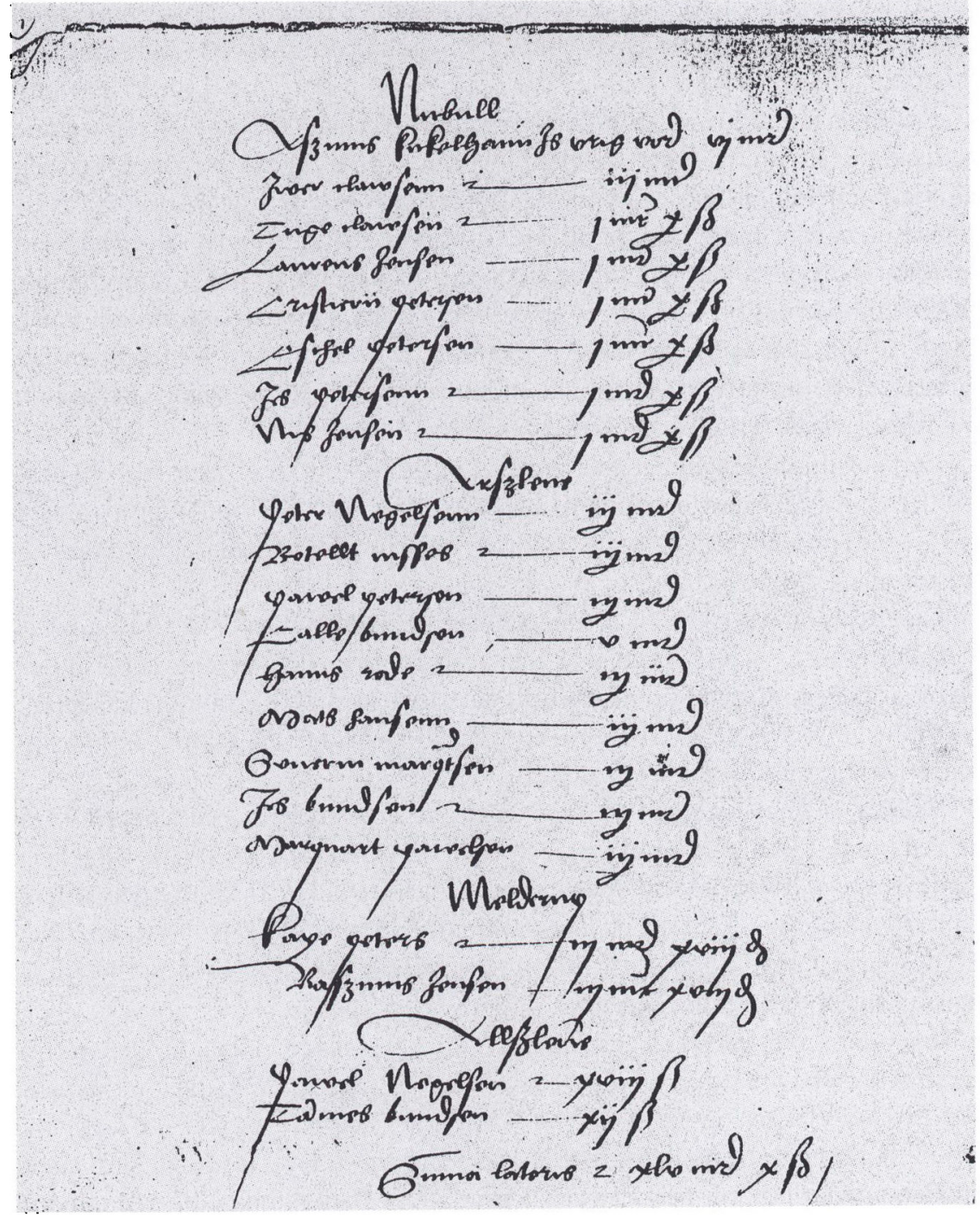

Side af pengeregnskabet for Aabenraa amt 1535. Alle skatteyderne er navnt ved navn, f.eks. ser man under Nybøl, at »Asmus Kukelhan er fri(taget) for 6 mark (skat) «. Original $i$ Rigsarkivet.

\section{Slottets beboere}

I vore dag er der et stort antal mennesker i den amtslige administration. I den tid, der her studeres, 1530'erne, var det derimod en langt mindre skare, der stod for den offentlige forvaltning. 
Der var for det første amtmanden selv. Som alle de slesvigske og holstenske amter havde Aabenraa amtmænd af de bedste ridderslægter. 1520-23 var det Benedict von der Wisch, 1523-28 Benedict Pogwisch, 1528-35 Claus von der Wisch, og i tiden 1535 til 1546 stod Christian III's mand Hieronimus Rantzau til Bülk for styret ${ }^{9}$. Sidstnævnte fik selv en årsløn på 100 mark samt 20 mark til sommertøj og 32 mark til vintertøj.

Amtmanden havde folk til hjælp. Af Hieronimus Rantzaus regnskaber fremgår deres antal. De fik deres løn udbetalt $i$ penge to gange om året, så deres samlede årsløn kan udregnes ved at lagge sommer- og vinterlønnen sammen. Kun for jægerens vedkommende er der det lille problem, at han fik en del af lønnen udbetalt i klæde; det fremgår, at han både i sommeren 1535 og i 1538 modtog 6 alen harderwijker klæde ${ }^{10}$ til 3 marks værdi ud over sin løn på 4 mark. 1539 fik han derimod øjensynligt penge til selv at foretage indkøbet til sin jægerdragt (tab. 1):

Tabel 1. Årslønninger i mark lybsk udbetalt på Aabenraa slot 1535, 1538-39.

\begin{tabular}{|c|c|c|c|}
\hline Person & 1535 & 1538 & 1539 \\
\hline 1. Skriveren & $23 \mathrm{mk} 8 \mathrm{sk}$ & $23 \mathrm{mk} 8 \mathrm{sk}$ & $23 \mathrm{mk} 8 \mathrm{sk}$ \\
\hline 2. Jægeren & $14 \mathrm{mk} 8 \mathrm{sk}$ & $14 \mathrm{mk} 8 \mathrm{sk}$ & $14 \mathrm{mk} 8 \mathrm{sk}$ \\
\hline 3. Engelke Kok & $8 \mathrm{mk}$ & $8 \mathrm{mk}$ & $8 \mathrm{mk}$ \\
\hline 4. Sluteren & $8 \mathrm{mk}$ & $8 \mathrm{mk}$ & $8 \mathrm{mk}$ \\
\hline 5. Dennes dreng & $3 \mathrm{mk} 4 \mathrm{sk}$ & $3 \mathrm{mk} 4 \mathrm{sk}$ & $3 \mathrm{mk} 4 \mathrm{sk}$ \\
\hline 6. Molleren & $8 \mathrm{mk}$ & $8 \mathrm{mk}$ & $8 \mathrm{sk}$ \\
\hline 7. Fiskeren & $6 \mathrm{mk}$ & $6 \mathrm{mk}$ & $6 \mathrm{mk}$ \\
\hline 8. Humlemesteren & $6 \mathrm{mk}$ & $6 \mathrm{mk}$ & $6 \mathrm{mk}$ \\
\hline 9. Voetknecht I & $8 \mathrm{mk}$ & $8 \mathrm{mk}$ & $8 \mathrm{mk}$ \\
\hline 10. Voetknecht II & $4 \mathrm{mk}^{*}$ & $8 \mathrm{mk}$ & $8 \mathrm{mk}$ \\
\hline 11. Portneren & $3 \mathrm{mk}$ & $3 \mathrm{mk}$ & $3 \mathrm{mk}$ \\
\hline 12. Mejersken & $3 \mathrm{mk}$ & $3 \mathrm{mk}$ & $3 \mathrm{mk}$ \\
\hline 13. Hendes pige & $2 \mathrm{mk} 2 \mathrm{sk}$ & $2 \mathrm{mk} 2 \mathrm{sk}$ & $2 \mathrm{mk} 2 \mathrm{sk}$ \\
\hline 14. Kohyrden & $3 \mathrm{mk} 4 \mathrm{sk}$ & $3 \mathrm{mk} 4 \mathrm{sk}$ & $3 \mathrm{mk} 4 \mathrm{sk}$ \\
\hline 15. Fyrbøderen & $2 \mathrm{mk} 8 \mathrm{sk}$ & $2 \mathrm{mk} 8 \mathrm{sk}$ & $2 \mathrm{mk} 8 \mathrm{sk}$ \\
\hline
\end{tabular}

Med * er angivet en person, der kun modtager et halvt års løn.

På slottet var altså i alt beskæftiget 15 personer. Et blik på tabellen viser, hvor konstant både løn og antal personer var over de tre år, der her følges.

Selve det bureaukratiske element var ikke særlig udviklet. Faktisk ser administrationen ud til at bestå af kun amtmanden selv og skriveren. Alle andre personer udførte andre og mere praktiske funktioner. Hans og senere Matz Sluter tog sig sammen med en dreng af fangerne på slottet og vel af sikkerhed i det hele taget, hjulpet af de to bevæbnede vagter, "Voetknecht". Varmen på slottet skabte fyrbøderen. Kokken fik sine råprodukter fra flere kilder. Højt på strå var jægeren, der skaffede vildt til slotsherrens bord og sikkert også 
havde opsynet med skovene. Af regnskabet fremgår det bl.a., at han drev hjortejagt. Hans bytte suppleres af, hvad fiskeren og humlemesteren bragte. Køerne ude på ladegården blev passet af mejersken og hendes pige samt kohyrden, mens mølleren på borgmøllen kunne levere friskmalet mel. Det korn, han malede, kom imidlertid ikke fra slottets egne marker, men var resultatet af det afgiftssystem, som amtet hvilede på.

\section{Amtets indtægter}

Under amtmanden stod først og fremmest et landområde, Aabenraa amt. Her havde han opsyn med kongelige afgifter og skatter, med møller og skove, med jurisdiktion og orden. Hertil kom indkrævningen af jordafgift fra en række borgere i Aabenraa og toldopkrævningen i Toldsted og Aabenraa.

Det område, eller rettere de gårde, der hørte under amtmanden, kan bestemmes ud fra regnskabernes indtægtsregistre. Ifølge regnskaberne fra 1535 og 1538 var der $\mathrm{i}$ alt 11 sogne med gårde, som betalte til amtet disse år. De fordelte sig således (tab. 2):

Tabel 2. Antal gårde under Aabenraa slot, fordelt på sogne.

$\begin{array}{ll}\begin{array}{l}\text { Nr. Rangstrup herred: } \\ \text { Bevtoft s. }\end{array} & 3 \mathrm{gd} \\ \text { Aabenraa by (Kolstrup) } & 4 \mathrm{gd} \\ \begin{array}{l}\text { Sønder Rangstrup herred: } \\ \text { Bedsted s. }\end{array} & \\ \text { Hellevad s. } & 15 \mathrm{gd} \\ \text { Egvad s. } & 32 \mathrm{gd} \\ \varnothing . \text { Løgum s. } & 20 \mathrm{gd} \\ \text { Rise herred: } & 36 \mathrm{gd} \\ \text { Løjt s. } & 72 \mathrm{gd} \\ \text { Rise s. } & 48 \mathrm{gd} \\ \text { Hjordkær s. } & 47 \mathrm{gd} \\ \text { Bjolderup s. } & 11 \mathrm{gd} \\ \text { Lundtoft herred: } & 30 \mathrm{gd} \\ \text { Varnæs s. } & \end{array}$

Der var tale om i alt 318 gårde, der væsentligst lå nord og syd for Aabenraa, og så ude i Varnæs sogn. Amtet var som helhed ikke stort, men udgjorde dog et velafrundet område med en god koncentration i det frugtbare østland i Løjt sogn.

I området lå fem møller, som hver bidrog med indtægter til lensmanden gennem afgifterne for at male mel. I perioden 1535-39 omtales hvert år borgmøllen ved slottet, Runde Mølle ved Løjt Kirkeby, Lillemølle og Blåmølle, der begge lå ved Varnæs samt Hellevad mølle. 
Fra disse gårde og møller indbetaltes til lensmanden dels de årlige afgifter i penge og naturalier, dels skat, som kun blev opkrævet i visse år. Ud fra regnskaberne kan vi kvantificere indbetalingerne. Lad os først se på korntilforslerne, som de kendes fra 1535 (tab. 3):

Tabel 3. Korntilførsler til Aabenraa amt 1535

Fast årlig afgift af gårde:
Rug $\quad 4$ læster 3 ørtug
Byg $\quad 3$ læster 3 ørtug
Havre $\quad 6$ læster 21 ørtug 3 skæpper
Afgift af møller:
Rug $\quad 15$ læster 5 ørtug 7 skæpper
Malt $\quad 3$ læster $221 / 2$ ørtug
Købt fra Flensborg, Sønderborg, etc.:
Malt $\quad 3$ læster $17 \frac{1}{2}$ ørtug

Anm: 1 læst $=24$ ortug.

Ud over fødevarer indbetalte de fleste af bønderne rede penge til slottet; kun Varnæs skilte sig ud i denne forbindelse, idet bønderne herfra normalt kun betalte korn i afgift. Omfanget af pengeydelserne fremgår af regnskaber fra 1535,1538 og 1539 (tab. 4):

Tabel 4. Indtægter i penge til Aabenraa amt (afrundet til hele mark lybsk). Totalsum efter regnskaber.

\begin{tabular}{lccc}
\hline Ar & 1535 & 1538 & 1539 \\
\hline Fast afgift af gårde & 970 & 892 & 892 \\
Told og oldenpenge & 404 & 667 & 432 \\
Bader og indfæstning & 257 & 549 & 663 \\
Skatterestancer & 136 & 21 & 509 \\
Skat & & & 2499 \\
\hline i alt & 1769 & 2108 & \\
\hline
\end{tabular}

Det ses, at amtmanden havde en gennemsnitsindtægt på de henved 2000 mark. De faste årlige indtægter, som betaltes af bøndergodset, delvist som fæsteafgifter, delvist som et levn af Valdemarstidens faste skatter, udgjorde henved halvdelen af indtægterne, undtagen i det år, hvor en ekstraordinær plovskat forrykkede billedet ${ }^{11}$. Told og oldenpenge gav fra $1 / 4$ til $1 / 3$ af indtægterne. En klar stigning synes at fremgå af indtægterne fra bøder og indfæstning, der sikkert også var det eneste punkt, hvor virkelige takstforhøjelser kunne placeres. Ekstraskatter kunne som den skat på en gylden af hver plov, der opkrævedes i 1539, viser, forbedre pengeindtagterne med $1 / 4$.

Det var, hvad lensmanden havde at holde hus med. Alle regnskaberne har en udgiftsside, der viser, hvordan han gjorde det. De tillader os at vise slottet i samspil med det omgivende samfund. 


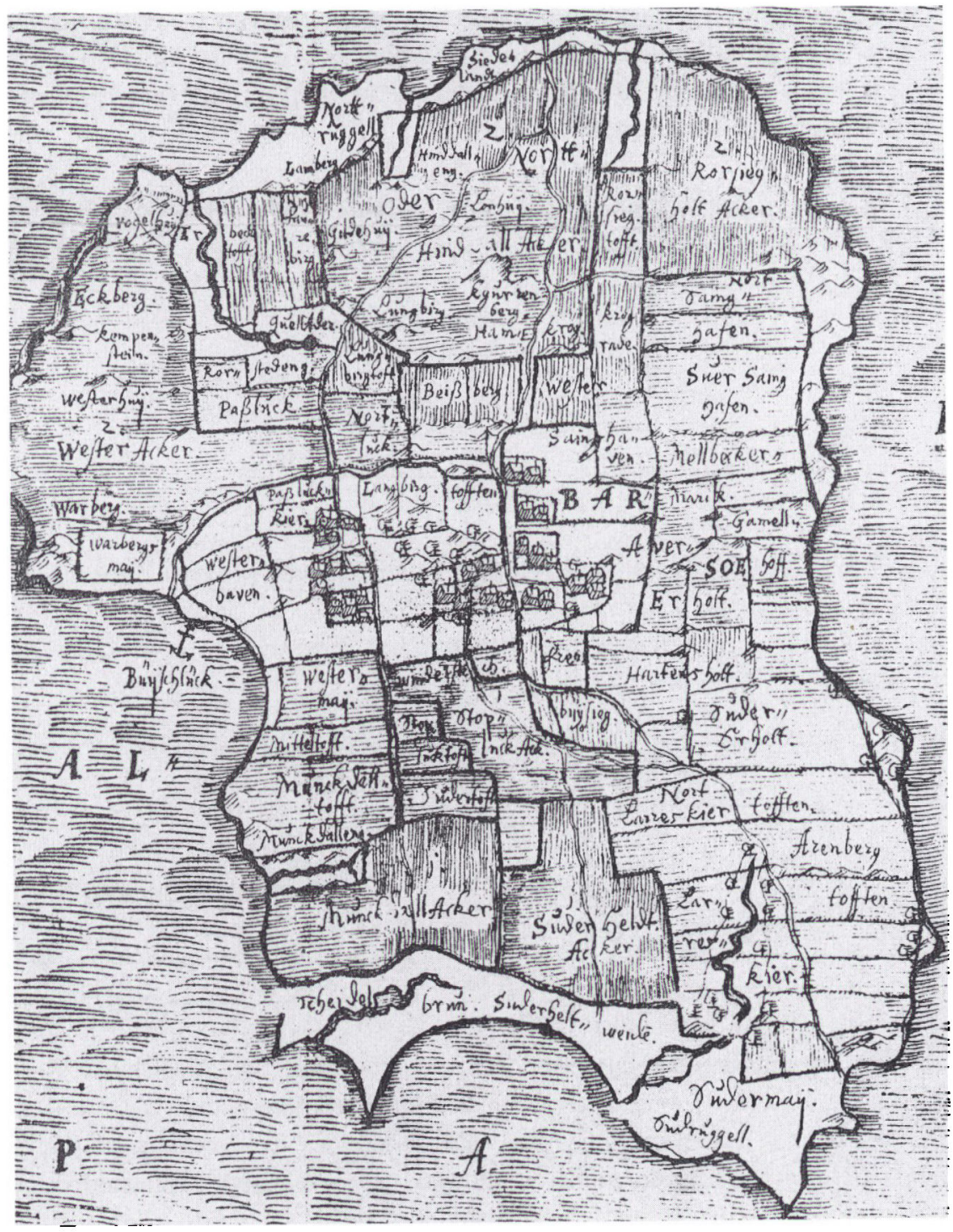

Af amtsregnskabet fra 1535 kan man se, at lybakkerne dette àr nedbrandte alle gårdene på Barso. Her ses oen pả et af de kort, som Johannes Mejer tegnede under sin opmåling af Aabenraa amt $i$ 164l. Gengivet efter Johannes Mejers kort over det danske rige, udg. af N.E.Norlund, bd. 3, 1942.

\section{Amtmandens virke}

Kornet blev brugt i slottets hushold, der var intet tilovers til salg. En stor del, nemlig 4 læster $1 \frac{1}{2}$ ørtug, bagtes til brød i slotskøkkenet, en endnu større del, 
der var maltet, bryggedes til øl: 8 læster 20 ørtug. En lille portion mel på tre skæpper månedligt blev overgivet til fårehyrden, som passede whedefårene ${ }^{12}$, og næsten al havren blev brugt til foder til lensmandens og forbirejsendes heste. Den eneste større overførsel til andre steder var 1 læst havre, som blev sendt til Haderslev på kongens befaling.

Det var primært pengeindtægterne, som amtet igen sendte i cirkulation. Lad os se på, hvordan det skete.

For det første havde amtmanden pligter uden for sit amt. De udgifter, der var forbundet hermed, skulle refunderes, og vi kan derfor følge nogle af rejserne.

1536 var Hieronimus Rantzau forhindret $i$ selv at tage til Slesvig og aflægge regnskab for året 1535 , og derfor blev skriveren og en mand sendt af sted. De overnattede i Flensborg og blev i Slesvig i fire dage. I lobet af det forgangne år havde amtmanden imidlertid selv på Christian III's bud været i Itzehoe samt på landdagen i Rendsborg og havde på hjemvejen overnattet i Flensborg. 1538 foretog amtmanden også personligt rejsen til Slesvig for at aflægge regnskab. Denne rejse involverede et ophold i Flensborg på hen og tilbagevejen og 5 nætters indkvartering i Slesvig. 1539 krævede kongen, at Hieronimus Rantzau kom til Gottorp midt om sommeren; her blev han indkvarteret i "Kordes' hus«, hvor han også overnattede, da rejsen senere gik til Slesvig for at aflægge regnskab. Begge gange var der overnatninger i Flensborg, den ene gang i den rige rådmand Marquardt Hess' hus. Samme år opretholdt kongen store troppestyrker ved Holstens sydgrænse som følge af truslerne fra den tysk-romerske kejser Karl V. Amtmanden måtte følge sin militære tjenestepligt og slutte sig til. Han noterede udgifter for et »togt« til Bramstedt og for den tid han lå med hæren, wmit der rustinge«, "i marsken« og ved Itzehoe. Det fremgår, at Hieronimus Rantzảu med følge af beredne mænd er rejst via Flensborg, Slesvig til Rendsborg, Neumünster og så ud i marsken, hvor han opholdt sig et godt stykke tid; igen videre til Itzehoe, hvor opholdet heller ikke var kort; herefter hjem igen over Rendsborg til Gottorp med holdt $\mathrm{i}$ Kordes' hus, og endelig en sidste nat i Flensborg hos Marquardt Hess. Hertil kom så, at amtmanden to gange måtte møde op hos kongen i Rendsborg.

Amtmanden skulle som kongens tjener være rede, når der var behov. Det var sikkert besværligt for ham, men særlig dyrt var det ikke for amtet. De samlede udgifter til de nævnte rejser oversteg ikke et par hundrede mark.

\section{Gæster}

Langt dyrere og sikkert også langt mere tyngende var de mange forbirejsende gæster, som amtet måtte underholde. 


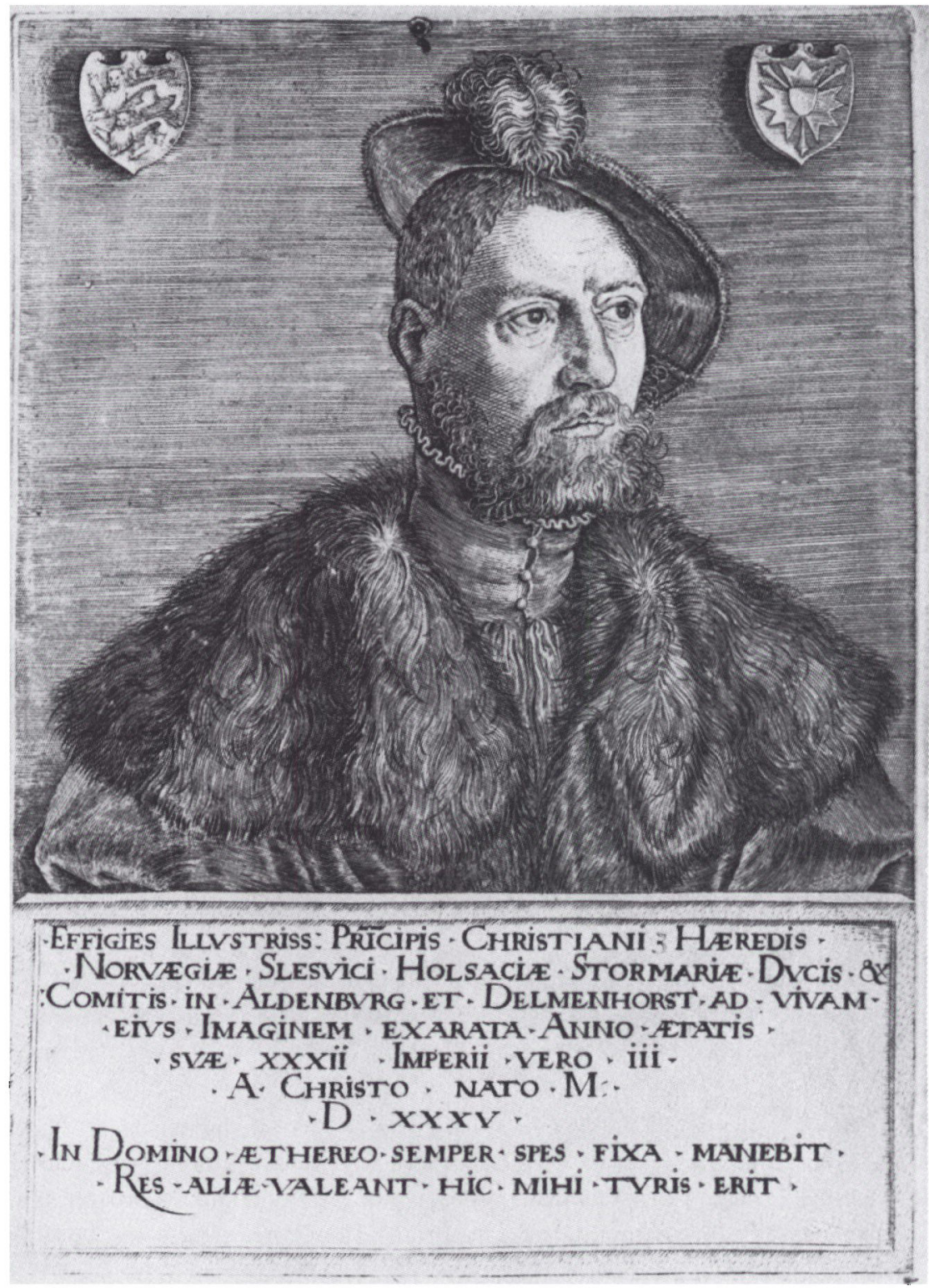

I 1530 'erne gastede Christian III hyppigt slottet i Aabenraa. På samme tid-i 1535 - udforte kunstneren Jacob Binck dette stik af Christian, inden han $i 1536$ blev kronet til dansk konge.

Der var for det første kongen selv. Hieronimus Rantzau's herre var reformationens forkæmper kong Christian III, der i anden halvdel af 1530'rne, da 
regnskaberne blev skrevet, var travlt beskæftiget med at samle og sikre sit kongerige samt hertugdømmerne. Frem til 1544 herskede han udelt over Slesvig og Holsten, så mange rejser her var nødvendige.

Den 11.februar 1535 kom kong Christian til Aabenraa, men tog dog efter et måltid hurtigt videre til Sønderborg for at udruste skibe, der skulle hjælpe ham med erobringen af Fyn. Igen 2. april kom kongen rejsende nordover fra Gottorp, spiste og kom så tilbage to dage senere på vej til Gottorp igen, travlt beskæftiget med at organisere et flådetogt mod lybækkerne. Den 25 . samme måned indkvarterede han sig med et følge på mere end 18 ryttere i Aabenraa for næste dag at rejse videre til landdagen i Rendsborg. Et par måneder senere, omkring Sankt Hans, var kong Christian med 18 beredne folk igen i byen på rejse mod Haderslev, hvorfra han noget senere vendte tilbage for at begive sig til slottet Gelting. Også udgifterne til herberget Toldsted indgik i amtsregnskabet, så vi kan se, at kongen 14. november 1535 kom her forbi.

I året 1538 noteredes der kun et kongebesøg, da kongen og dronningen $\mathrm{i}$ følgeskab med Melchior Rantzau indlogerede sig i Toldsted på deres vej mod Tørning slot. I 1539 kom kongen derimod flere gange, oftest på rejse mellem Gottorp og Haderslev slotte. 16. marts drog kongen sydover gennem Aabenraa og kom igen nordover til Haderslev på vej fra Gottorp 26. marts. På tilbagerejsen til Gottorp slot den 22.april var majestæeten indlogeret $\mathrm{i}$ byen med over 22 beredne mænd, mens mindst 24 heste fulgte ham, da han 30.april igen begav sig til Haderslev og overnattede i Aabenraa. Endnu et sidste besøg dette år fandt sted sidst på året 27.november.

Kongebesøgene vejede samlet økonomisk ganske tungt på amtet. Udgifterne til gæster forstørredes imidlertid betragteligt ved de mange, der rejste i kongens navn, og som amtmanden også skulle sørge for.

Som følge af de mange krigshandlinger og diplomatiske forhandlinger $i$ 1535 kom adskillige fremmede forbi Aabenraa. Feltherren Melchior Rantzau overnattede med adskillige heste "på Fyntoget«, dvs. på vej til det felttog, hvormed han skulle erobre Fyn. En række forbirejsende kan sættes i forbindelse med de nordtyske protestantiske fyrsters forsøg på at mægle i den kamp, der foregik med Lybæk ${ }^{13}$. Det gælder selve hertug Frans I af SachsenLauenburg $^{14}$, hertug Ernst af Brunsvig-Lyneborgs kansler Johan Forster samt kurfyrsten af Brandenburgs udsending Frantz van Bartensleue und Schilling. De fremmede fyrster, der dette år søgte kontakt med Christian III, repræsenteredes også af udsendinge fra den svenske konge og den franske konges mand hr. Peter Luckennsen. 1538 kom først de danske rigsråder med over 23 heste til Aabenraa og overnattede her i to nætter på rejse fra Gottorp og op i Jylland, dernæst indfandt hofmesterinden sig med nogle jomfruer og blev også i to nætter. At otte vognheste og Marcus Wagendriuer ifølge regnskabet fulgte 
hofmesterinden må betyde, at damerne rejste med vogn. Blandt de kvindelige rejsende var en oldfrue og hendes pige, der kom fra København. Den dygtige kongelige sekretær og udlandsekspert Georg Cörper passerede på vej til Tørning slot ${ }^{15}$. Af fremmede udsendinge indfandt sig på Aabenraa slot i 1538 bl.a. den udsendte Klumckenbeke fra hertugdømmet Preussen på vej til kongen i København og 5 ambassadører, der kom herfra. I 1539 overnattede engelske gesandter i Aabenraa; men den mest kendte besøgende var dog selveste Luthers nære ven, reformatoren Johann Bugenhagen. Omtrent ved Sankt Hans kom denne dygtige kirkemand med følge "fra Danmark « og sov i Aabenraa sammen med kusken, Wulf Wagendriuer, for næste dag at drage videre mod Hamburg ${ }^{16}$.

Kongen og de folk, der havde hans tilladelse til overnatning, forårsagede altså amtet betydelige udgifter. Udgifterne fordelte sig på køb af varer og på udgifter til indkvartering, for slottet var for lille til at rumme alle forbirejsende. Vi skal nu kaste et blik på de logier, der stod til rådighed.

\section{Indkvartering}

Det var borgerpligt at tage mod kongens gæster, og en række Aabenraaborgere havde huse til at gøre det. Det er nok værd at fremdrage disse steder, dels fordi så lidt er kendt om Aabenraa ved denne tid, dels fordi det bidrager til at forklare, hvordan amtmanden kunne klare sine pligter.

Der var for det første borgmesteren Nis Stalknecht. I 1535 bespiste og skaffede han øl til kongen og dennes svende samt Mogens Gøye. I 1538 var Laurentz Brockdorf samt en portsvend fra Gottorp hos ham og spiste, og 1539 sørgede han igen for øl til kongen og dennes drabanter under deres besøg.

Et endnu større hus end borgmesteren havde dog utvivlsomt en mand ved navn Hinrik Kake. 1535 overnattede og spiste hos ham både adelsmændene Melchior Rantzau, Michael Hesten, Laurens Brockdorf og diplomater fra Lyneborg, Frankrig og Sverige. Wulf Vogndriver fik kvarter hos Kake med 4 heste, og 2 andre vognmænd med 10 heste modtog øl samt foder til dyrene. Vi må tro, at Anne Kakes, der samme år solgte ol til amtmanden for $1 / 2$ mark, var hans hustru. 1538 var Kakes hus ligeledes fuldt belagt. Blandt andet overnattede danske rigsråder her med 19 heste og diplomaterne fra Preussen med ganske tilsvarende antal heste. Samme år solgte Anne Kakes 8 stoveken

Johann Bugenhagen (1485-1558), der var superintendent $i$ Kursachsen og professor ved universitetet $i$ Wittenberg, deltog i årene fra 1537 til 1539 aktivt i den danske kirkes reformation og overnattede $i$ forbindelse med sit arbejde i 1539 i Aabenraa. Foto efter stik i Det kongelige Bibliotek. 


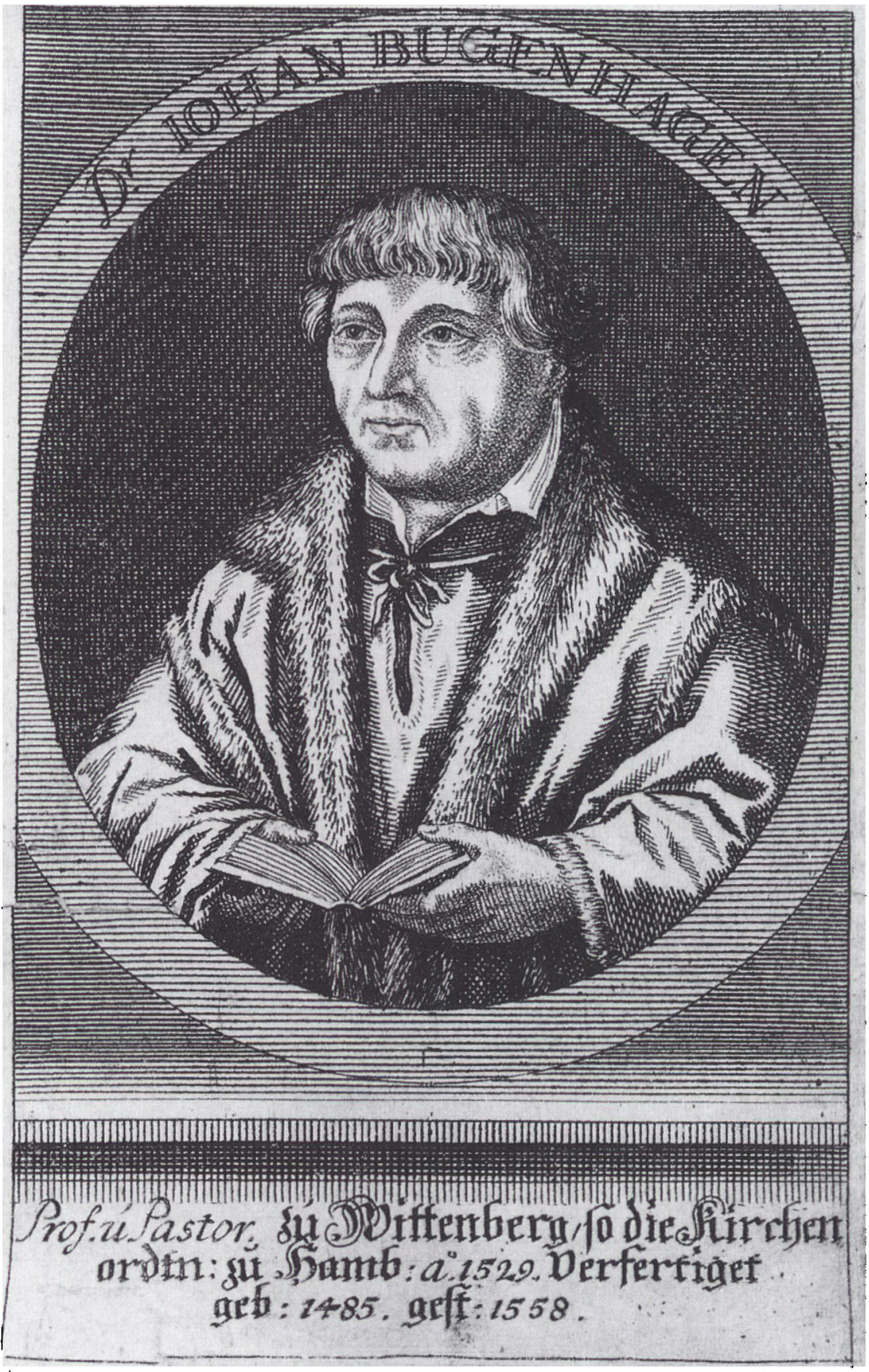


vin til amtmanden. 1539 var det så, at den bekendte Bugenhagen kom til Hinrik Kakes hus og spiste for hele 8 mark 6 skilling.

Det tredje betydelige overnatningssted var hos Jørgen Petersen. I $1535 \mathrm{kom}$ hos ham bl.a. kongen og hans folk med $i$ alt $\mathbf{4 4}$ heste, en mand ved navn Tønnies van Schowenborch med 18 heste og Wulf Vogndriver med 4 vognheste. 1538 indlogerede sig til en begyndelse rigsråderne med 14 heste og herefter andre rejsende med i alt 8 heste. I 1539 var først 18, så 6 og så 22 kongelige heste på stald hos Jørgen Petersen.

Som mindre væsentlige huse $\mathrm{i}$ byen i denne forbindelse fremstod Peter Elnes og Sven Negelsens, Peter Hansens og Jørgen Simens, Hinrich Kocks og Laurits Petersens, Jørgen Gregersens og Kirstine Gregers. At nogle af de sidstnævnte udøvede købmandskab antydes af, at både Peter Hansen og Peter Elne solgte flere tønder sild til amtmanden. Sidstnæunte Peter Elne var forøvrigt så uheldig, at han i 1538 kom til at slå en landsknægt ihjel måske en af hans logerende? - og, at han derfor måtte betale den høje 40marks bøde til amtet.

Uden for Aabenraa lå gården Toldsted ved hærvejen som sæde for amtmandens tro tolder Asmus Arnkiel, eller som han også kaldtes - efter en ølsort Asmus Kukelhan, der opretholdt et herberg for de mange forbirejsende ${ }^{17}$. Kongen kom til Toldsted 14.november 1535, spiste en okse til 5 mark samt sigtemelsbrødet skonrog og hvedebrød til 1 mark, og drak 1 tønde hamborgsk øl til 5 mark og 5 stoveken vin til $2 \frac{1}{2}$ mark; hertil kom så skinke og smør. Senere samme år indlogerede en vis Doctor Johan Carion sig her, og en kældersvend, der af kongen var sendt til Husum for at hente vin, måtte sove her en nat. Forbi en nat kom også dels en bøsseskytte med kanoner, dels to navngivne bøsseskytter, hvoraf den ene var i tjeneste hos hertugen af Lyneborg - krigen i kongeriget krævede materiel og professionelle krigere, og Asmus Kukelhan stod parat til at hjalpe med øl og foder. 1538 overnattede selve kongen og dronningen igen $\mathrm{i}$ Toldsted på vej mod Tørning. Under opholdet blev der fortæret 1 okse, 7 lam, 3 sider flæsk, 30 høns, torsk og laks, skonrogger og hvedebrød, $1 / 8$ tønde smør og 4 tønder øl. Desuden kom en række andre personer til Asmus' hus, bl.a. Melchior Rantzau og endnu en kældersvend på vej til Haderslev med vin til kongens bord.

Et net af solide husejere, som amtmanden havde gode kontakter til, sørgede for, at de mange forbirejsende under kongelig beskyttelse kunne få passende underhold under deres ophold i Aabenraa og ved vejstationen i Toldsted. Denne ordning var givetvis til alles tilfredshed, da de regninger borgerne mødte frem med pænt blev betalt. Det må siges, at indkvarteringssystemet kom byens og egnens erhvervsliv til gode, men de fleste af de penge amtmanden gav ud var dog til varer, der skulle bruges på slottet. Hvor købtes nu disse varer? 


\section{Indkøb i Aabenraa by og hos egnens bønder}

I selve Aabenraa by, der også dengang var af beskeden størrelse og vel kun havde omkring 600 indbyggere ${ }^{18}$, kunne de basale forbrugsvarer erhverves. Brød købtes hos en bager ved navn Negels Becker. 1538 solgte han skonrogger af sigtemel såvel som det dyrere hvedebrød gennem hele året for 3 mark 4 skilling, 1539 samme slags bagværk for 4 mark $^{19}$. Det stedlige øl, »kukelhan«, købtes i 1539 til 1 mark tønden. I byen kunne også købes talg, som Hans Kræmmer i 1538 solgte for 30 skilling af; fra fjorden var der frisk fisk at få, og kød kunne i små partier købes på torvet eller af byens handlende. Hele to okser solgte en borger ved navn Hans Black for 9 mark 4 skilling til amtet $\mathrm{i}$ 1538.

Et virkeligt stort indkøb i byen repræsenterede også den halve læst malt for 18 mark, som Hans Tolder »binnen apenrade« solgte i 1538. Man skaffede sig yderligere malt til brygning på borgen ved at sende den byg, der indkom i amtets kornafgifter, ud i byen til maltning. Adskillige Aabenraaborgersker må have haft køller, hvor byg kunne røges til malt. Det fremgår, at to kvinder og en mand i 1535 tjente penge ved at fremstille malt af over 3 læster byg, og ganske lignende forhold gjorde sig gældende i 1538 og 1539.

Umiddelbart nordvest for Aabenraa ligger Kolstrup, der nærmest udgjorde en slags humlehave for byen. Et vidnesbyrd om den omfattende produktion er det, at en bonde ved navn Iver Jensen i 1538 solgte 180 skæpper humle til amtmanden for 16 mark 14 skilling. Samme mand afhændede i 1539 dels et par okser for 9 mark 4 skilling, dels igen et betydeligt parti humle på 128 skæpper til 10 mark 10 skilling, så han må have haft en pæn stor avl. Dette leder videre til spørgsmålet om, hvad egnens bønder generelt solgte til amtet. Lad os forsøge at sammenfatte varesalgene i tabel 5:

Tabel 5. Antal varer solgt fra Aabenraa amts bønder til amtet 1535, 1538-39.

\begin{tabular}{lccccccc}
\hline Sogne & Heste & Okser & Lam & Høns & Træsalg & Fiskenet & Kornsalg \\
\hline Hellevad & & 9 & & & & & \\
Egvad & & 9 & & & & & \\
Øster Løgum & 2 & 15 & & & & & 1 \\
Løjt & 12 & 7 & & & 2 & 3 \\
Hjordkær & & & 5 & 12 & & & \\
Varnæs & & & & & & & \\
\hline
\end{tabular}

Mest markant er købene af okser fra de fire sogne Hellevad, Egvad, Øster Løgum og Løjt. De turde være klare vidnesbyrd om, at nogle bønder her på dette tidspunkt havde engageret sig $i$ en ikke ringe produktion af kødkvæg. De priser bønderne fik pr. okse var gennemgående 5 til 6 mark. Mange af oksesælgerne var øjensynligt blot gennemsnitsbønder, enkelte hæ- 
ver sig dog over de andre. På gården Kopsholt i Øster Løgum sogn sad herredsfogeden Nis Brun, der 1538 for 11 mark solgte 2 okser til borgkøkkenet, da amtmanden for en tid havde 20 landsknægte stationeret, og som igen i 1539 solgte en okse for 5 mark til slottet. På en gård i Barsmark i Løjt sogn, formentlig Vestre Paulsgård, boede Negels Pawlsen, der 1538 solgte 2 okser til 10 mark, 1 okse til 6 mark 12 skilling, og 2 okser til 12//2 mark - om de sidste siges det, at de blev solgt om sommeren. Rige bønder var utvivlsomt også Hans og Christen Marquartsen på Vestre Elsholm i Løjt sogn, der 1539 udover en posthest til 11 mark, afhændede 4 okser til slottet. Der kan have været tale om opkøbere, men sandsynligt er det, at de registrerede salg er vidnesbyrd om, at Løjtgårdene allerede her i 1500-tallets første år kunne præstere 4-6 færdigfedede okser om året. I dette kvægbaserede landbrug finder man forudsætningerne for den udvikling af individuel drift, der slog igennem på egnen fra denne tid ${ }^{20}$.

På den anden side er det lige så markant, at Aabenraa amt ikke var et kornsalgsområde. Det kunne jo skyldes, at amtet dækkede sit kornforbrug ved de pligtige ydelser, men som det snart skal vises, var det ikke tilfældet. Det eneste område, hvor kornkøb blev foretaget hos bønder i Aabenraa amt, var, bortset fra et lille havrekøb i Løjt, åbenbart Varnæs sogn. Herfra købtes 153810 ørtug havre af præsten hr. Johan Krawinkel, 15394 ørtug havre for $4 \frac{1}{2}$ mark af bonden Peter Jepsen i Bovrup, mens Jes Andersen i selve Varnæs, der i 1539 havde solgt 5 lam og 12 høns, året efter afhændede 12 ørtug byg for $i$ alt 18 mark.

Udover købet af varer viser amtsregnskaberne, at man fra tid til anden på borgen kunne udnytte håndværkere fra landsbyerne. Peter Jørgensen fra Brunde i Rise sogn var således beskæftiget med at reparere en ålekiste, og en smed fra Løjt Kirkeby leverede nagler til et nyt møllehjul til Runde Mølle.

Amtmandens indkøb $\mathrm{i}$ hans eget amt har givetvis ikke været uvæsentlige for borgere og bønder. De har for enkelte, men dog også kun for enkelte, repræsenteret årets hovedomsætning. Bageren Peter Negelsen i Aabenraa har næppe haft bedre kunde end slottet, og bonden Negels Pawlsen fra Barsmark har nok solgt alle sine okser til amtmanden.

\section{Indkøb uden for det nære opland}

Uden for lenet købte man hovedsagelig i byerne, selv om enkelte bondesælgere også bragte deres varer over amtsgrænsen. En snes kilometer mod syd lå den store handelsby Flensborg. Her hentedes ofte varer. Vareindkøbene i Flensborg kan sammenfattes i tabel 6: 
Tabel 6. Varer indkøbt til Aabenraa slot fra Flensborg 1535, 1538-39.

\begin{tabular}{|c|c|c|c|}
\hline & 1535 & 1538 & 1539 \\
\hline hamborgsk øl & $2 \mathrm{td}$ & & \\
\hline kakebille ol & 2 td & & $1 \mathrm{td}$ \\
\hline $\operatorname{vin}$ & 5 stoveke & & \\
\hline eddike & 5 td & $6 \mathrm{td}$ & $8 \mathrm{td}$ \\
\hline olie & $5 \mathrm{pd}$ & $6 \mathrm{pd}$ & for $11 / 2 \mathrm{mk}$ \\
\hline skonrogge + hvedebred & for $1 \mathrm{mk}$ & & \\
\hline skånsk sild & $3 \mathrm{td}$ & & $4 \mathrm{td}$ \\
\hline stokfisk + sælspæk & & & for $2 \mathrm{mk} 1 \mathrm{sk}$ \\
\hline humle & 6 dromt & 3 dromt & \\
\hline malt & 6 artug & 1 læst & \\
\hline lyneborgsalt & l td & 2 skæpper & \\
\hline drikkeglas & for $10 \mathrm{sk}$ & for $1 \mathrm{mk}$ & \\
\hline hvidtekalk & & & for 12 sk \\
\hline tjare & & & for $30 \mathrm{sk}$ \\
\hline
\end{tabular}

Flensborg var, som det fremgår, allerede dengang byen, hvor man hentede fremmed øl og vin. Vigtigere var dog eddike, sild, olie ("manolie(), malt, humle, lyneborgsalt samt drikkeglas. Man handlede hos et større antal personer, f.eks. solgte både storkøbmanden Marquardt Hess og en borgerske ved navn Cissel Boies $ø l$ og vin. Mette Vesters solgte 6 pund olie for 12 skilling, mens Iver Hochberge fik 2 mark 12 skilling for 1 tønde lyneborgsk salt, og Ludolphus Opperheim var sælgeren af en hel læst malt til 30 mark. Ud over varerne kunne man i Flensborg hente en specialist som en glarmester, da slottet skulle have nye vinduer.

Langt mindre betydning end nabobyen mod syd, havde den mod nord: Haderslev. I 1535 tilkaldtes ganske vist 2 murere herfra, der skulle mure en ny bageovn ved slottet, men i 1538 blev der slet ingenting købt her. I 1539 benyttede man sig af byens gode leverancer af drikkevarer. Man fik leveret både vin af tre omgange og 1 tønde af Egernførdes kakebilleøl. Kakebilleøllet ankom i ikke ringe mængder ad søvejen til Haderslev, og vin blev bl.a. ført hertil ad landevejen fra Ribe.

Sønderborg og Als fremstod som kornleverandør. 1538 solgte adelsmanden Sivert van Qualen, som boede i Sønderborg, men ejede Egeskovgård i Avnbøl, 2 ørtug havre til Aabenraa, og han havde følgeskab af en hr Hans i Sønderborg, der solgte 14 ørtug havre. Malt blev dette år købt tre gange af sønderborgere, i alt 1 læst 20 ortug til den betydelige pris af $65^{1 / 2} 2$ mark. 1539 indkøbtes 12 ørtug malt af en borger i Sønderborg og $21 \frac{1}{2}$ ørtug havre af den alsiske adelsmand Wulf Sture til Gammelgård og Hellevedgård.

Kornleverancerne kunne så suppleres af skibstransporter fra andre syddanske områder. Fra Svendborg kom Hans Petersen, der afhændede 1 læst malt for 40 mark; fra Nakskov Kersten Nansen med 12 ørtug byg og Asmus 
Galmansen med $16^{1 / 2}$ ørtug 1 $1 / 2$ skæppe byg ${ }^{21}$. Tydeligt er det, at Aabenraaegnen ikke var selvforsynende med korn.

Fra Vestslesvig fik man det billige frisiske salt. Det kunne købes i Tønder, som det blev i 1535, hvor en svend blev sendt hertil to gange for at hente $1 \frac{1}{2}$ læst frisersalt eller i 1539, hvor 9 tønder af saltet afhentedes. Imidlertid kunne man også gå direkte til producenten, både i 1538 og 1539 købte man til slottet salt hos Jens Duysen i Risum Mose; den første gang 16 tønder til 16 mark, den anden gang 2 læster til 24 mark.

Kontakten med den store havnestad Husum ved vestkysten var ikke intensiv, til gengæld kunne man få dyre varer herfra. Den fornemme husumer Herman Hoyer, også kaldet "lange Harmen«, leverede i 15351 møllesten til Runde Mølle for 26 mark samt i 15383 møllesten til Blåmølle, Runde Mølle og Lille Mølle for et samlet beløb af 91 mark. Møllesten importeredes fra rhinske brud, og udgjorde en solid indtægtskilde for vestkystens handlende. Også fra Husum kom en specialhåndværker som glarmesteren Cort Munge, der 1539 satte ruder i på Aabenraa slot.

Den vigtigste handelspartner for Aabenraa slot var dog Ribe, men handelen her var, i modsætning til den anden betydelige indkøbsby, Flensborg, koncentreret på kun et par varer og begrænset til ganske bestemte tider af året.

Den ene vigtige indkøbsartikel fra Ribe var fisk. Aabenraas fiskeindkøb er sammenstillet $i$ tabel 7:

Tabel 7. Fiskeindkøb til Aabenraa slot fra Ribe. 1535, 1538-39 (antal fisk).

\begin{tabular}{lcccccc}
\hline & Faste 1535 & Skt. Hans 35 & Faste 38 & Skt. Hans 38 & Faste 39 & Skt. Hans 39 \\
\hline hvidling & 1000 & 1750 & 750 & 3000 & 1750 & 2250 \\
skuld & 500 & 1500 & 500 & 2500 & 500 & 2500 \\
kabeljau & 40 & 120 & 40 & 110 & 40 & 80 \\
rokke & 20 & 110 & & 120 & & 160 \\
sømrokke* & & & & 80 & & \\
mtepel «** & & & & 60 & & \\
\hline
\end{tabular}

* „Pillruchen «. ** muligvis rokkearten tærbe.

To gange om året drog man til Ribe for at købe fisk. Der var tale om de tørrede hvidling og skuld, en flynderfisk samt om rokker. Mindst købtes ved forårsmarkedet $\mathrm{i}$ marts, mest ved sommermarkedet, når bønder fra hele Vestkysten og øerne samledes i Ribe. Så sendte amtmanden en opkøber til markedet. Det kunne være herredsfogeden Nis Brun fra gården Kopsholt, som tog til begge markeder i 1535 og 1539 og hver gang fik nogle skilling for sin ulejlighed. Det kunne også være en Aabenraaborger som Hans Kremer, der var af sted i foråret 1538. Sælgerne var borgere i Ribe. Vi får navnene Termen Jensen med hustru Anne Termens og Hans Farsen. 
Endnu dyrere indkøb i Ribe repræsenterede okserne. I 1535 tog amtmandens skriver til »Ryper markede« og købte hele 31 okser for den betragtelige sum af 155 mark af oksehandleren Peter Bagge. For at få handelen i stand måtte skriveren blive 4 nætter $i$ Ribe.

Det andet betydelige oksemarked inden for rækkevidde fandt sted i Kolding. I efteråret 1539 drog Asmus Arnkiel hertil på amtmandens vegne og erhvervede 10 okser for 50 mark.

Hermed er grænserne for Aabenraa slots markedsområde udstukket: man bevægede sig inden for en radius, der i syd afgrænsedes af Flensborg og Husum, i nord af Ribe og Kolding. Inden for dette område udgjorde amtsadministrationen et af mange omdrejningspunkter i det lokale økonomiske liv.

\section{Aabenraa amts værdier}

Aabenraa slot satte en strøm af værdier i omløb i den organisme, som hertugdømmet Slesvig udgjorde. De fleste af værdierne forblev i selve amtet og kom slot og by til gode, mens kun en mindre del røg ud af systemet og videre til den kongelige administration. Dette fremgår ved en betragtning af pengeregnskabernes hovedsummer (tab. 8):

Tabel 8. Samlet indtægt, udgift og overskud i mark lybsk ved Aabenraa amt 1535, 1538-39.

\begin{tabular}{lrrr}
\hline & 1535 & 1538 & 1539 \\
\hline Indtagt & 1769 & 2108 & 2499 \\
Udgift & 1388 & 1718 & 1835 \\
Overskud & 381 & 390 & 664 \\
\hline
\end{tabular}

Som det ses, var det kun en brøkdel af de samlede indtægter, amtmanden kunne overrække kongen $\mathrm{i}$ form af overskud ved den årlige regnskabsaflæggelse $\mathrm{i}$ kammeret på Gottorp slot. Dette gjaldt selv for året 1539, hvor amtet ellers havde måttet betale en betydelig ekstraordinær skat. De fleste af de pligtige ydelser, som indkom til amtet, blev givet ud på lokalt slesvigsk plan, og de fleste penge igen i selve amtet. Der skete gennem disse udbetalinger en vis omfordeling af midlerne fra den brede masse af betalende bønder til udvalgte dele af byen Aabenraas borgere og enkelte mere produktive bønder. Særlig store pengemængder og sociale ændringer var der dog ikke tale om. Næppe nogen kunne leve alene af at levere til slottet. Selve de indtægter, der tilflød amtet, var jo også, som det fremgår, ret nøje tilpasset driften af slottet. I betragtning af at administrationen må karakteriseres som værende af dvargstørrelse, at garnisonen var yderst beskeden, og at slottet var diminutivt, må 


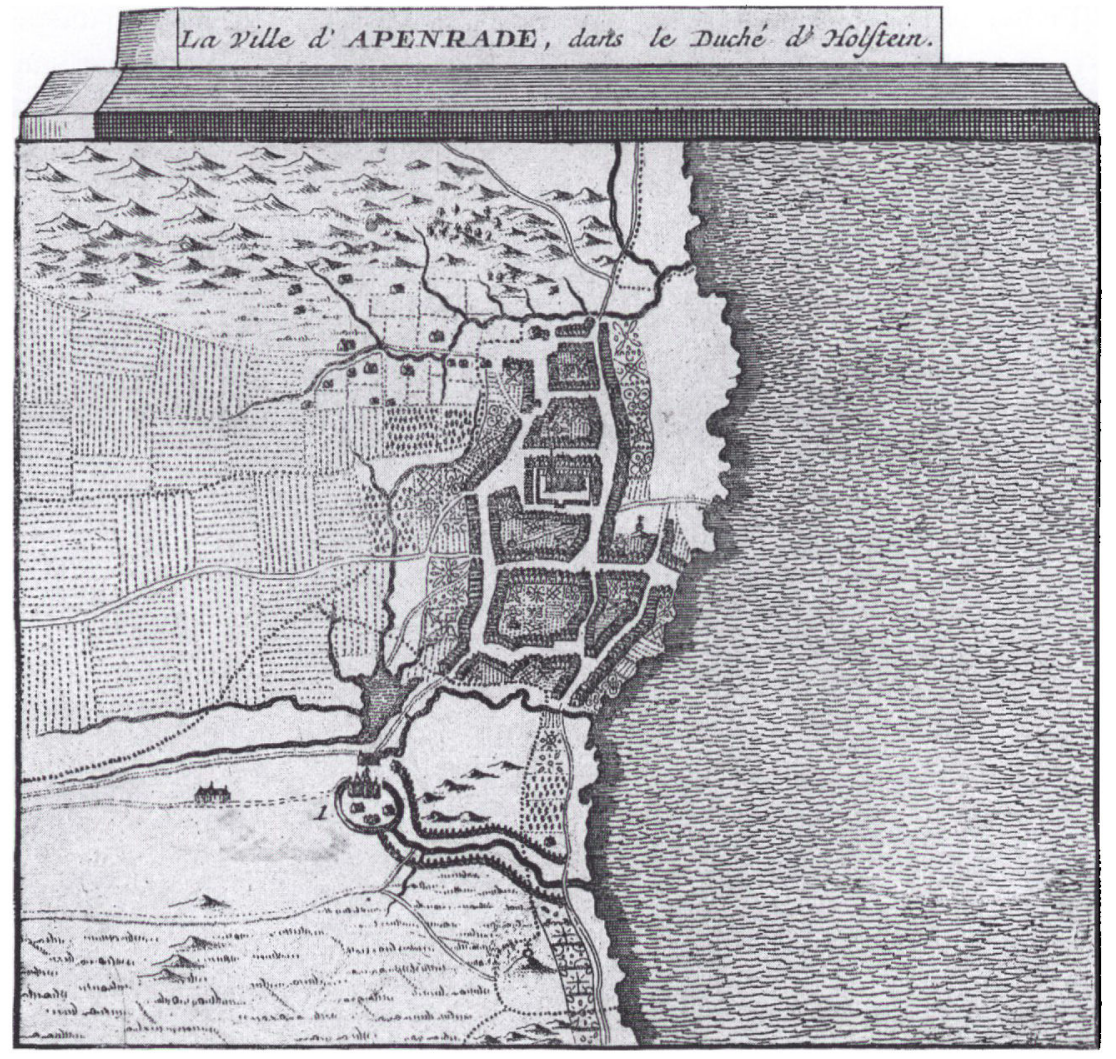

Brundlund slot fik lov at fylde pant på de gamle stik af Aabenraa by og omegn. På dette franske stik af "la Ville d'Apenrade, dans le Duchè d'Holsteinu fra shutningen af 1600-d̈rene er slottet markeret med tallet 1 . På en hoj sydost for slottet - Kapelbjerget - er det middelalderlige Skt. Andreas kapels beliggenhed markeret. Kortet findes $i$ landsarkivet i Aabenraa.

vi ledes til den konklusion, at det offentlige økonomisk set ikke vejede tungt på samfundet og i meget var til gavn for det. Naturligvis glædede det aldrig skatteyderne at betale. I 1538 indkasserede amtet således en gigantisk bøde på 115 mark fra 6 bønder i Hellevad, der havde skjult noget jord for skatteopkræveren. Kunne man snyde i skat, gjorde man det. Men som helhed kan det konkluderes, at forvaltnings- og administrationsomkostningerne ikke hævede sig til afskrækkende højder. Aabenraa amts beboere levede faktisk i givtig symbiose med deres amtsadministration. 


\section{NOTER}

1. Jeg vælger $\mathrm{i}$ det følgende betegnelsen amt istedet for len, da det er i overensstemmelse med den sprogbrug, der vandt indpas fra o. 1500. Jfr. dog at Aabenraas naturalieregnskab fra 1535 har titlen »Register des lhens A penrade«.

2. Rigsarkivet, Kbh. 1523 30.april. Inventar for Aabenraa slot. Regnskaber fra hertugdømmerne aldre end 1580 . II Kongens arkiv. Rev. regnsk. Aabenraa amts inventar og regnskaber 1523, 1535, 1538-39. Gem. Arch. Cap XXIII, 11.

3. Rigsarkivet, Kbh. 1535. Pengeregnskab for Aabenraa len. Slesvigske og holstenske regnskaber før 1580. Kongens arkiv. Rev. regnskaber, 1523, 1535, 1538-9. Regnskabet over de faste pengeindtægter (»jordebog«) er udgivet Falkenstjerne og Hude: Sønderjyske Skatte og Jordebøger. Kbh. 1895-99 s. 133-145.

1535. Naturalieregnskab for Aabenraa len. Slesvigske og holstenske regnskaber før 1580. Kongens arkiv. Rev. regnskaber, 1523, 1535, 1538-9. Regnskabet over de faste naturalieindtægter (njordebog(1) er udgivet Falkenstjerne og Hude, s. 133-145.

4. Rigsarkivet, Kbh. 1538. Pengeregnskab for Aabenraa len. Slesvigske og holstenske regnskaber før 1580. Kongens arkiv. Rev. regnskaber, 1523, 1535, 1538-9.

5. Rigsarkivet, Kbh. 1539. Pengeregnskab for Aabenraa len. Slesvigske og holstenske regnskaber før 1580. Kongens arkiv. Rev. regnskaber, 1523, 1535, 1538-9. Heraf udgivet: regnskab over overskat (1 gylden af hver plov). Falkenstjerne og Hude (1895-99) s. 125-132.

6. Ang. kilderne til Aabenraas plyndring i 1523 se Mikael Venge: »Når vinden føjer sig ...«. Spillet om magten i Danmark marts-december 1523. Odense 1977, s. 41-42.

7. J.Hvidtfeldt og P. K.Iversen: Aabenraa Bys Historie, I, 1961, s.128.

8. Otto Madsen: Brundlund slot. En bygningshistorisk undersøgelse. Aabenraa 1970. Johannes Hertz: Brundlund - et næsten ukendt slot. Nationalmuseets Arbejdsmark 1986, s. 84-103.

9. Hieronimus Rantzau var fra $1512 \mathrm{i}$ hertugelig tjeneste. Efter amtmandstiden i Aabenraa var han 1546-50 amtmand på Nordborg. Han døde 1567. Danm. Adels Aarbog 1930, s. 164.

10. Klæde fra den hollandske by Harderwijk.

11. Af udgiftsregisteret i 1535-amtsregnskabet fremgår det, at gårdene på Barsø i fasten 1535 var blevet nedbrændt af lybækkerne, og at kongen refunderede dem $10 \frac{1}{2}$ mark af deres landgilde, der derfor må fratrækkes det $\mathrm{i}$ tabellen anførte beløb.

12. Et egentligt "Schæfferei« udviklede sig under Aabenraa amt i løbet af 1500-tallet. 1564 skal der have været 500 får. Landsark. Aabenraa. Top. Aabenraa amt. 1564. Beskrivelse af Brundlund slot og Aabenraa amt.

13. Jfr. L. Laursen: Danmark-Norges Traktater 1523-1750. Bd. 1, Kbh. 1907, s.213ff.

14. Rejste forbi 15.april 1535.

15. Om denne se Dansk Biografisk Leksikon. 3. udg., Bd. III, s.503.

16. Formodentlig på den videre rejse sydover overnattede Bugenhagen 4 dage i Hinrick Wantschers hus i Rendsborg, hvorfra en detaljeret regning er bevaret. Edward Hoop: Geschichte der Stadt Rendsburg. Rendsburg 1989, s. 132.

17. Jfr. H.V.Gregersen: Toldsted ved Hærvejen. Arnkielernes hjemstavn og Urnehovedegnens og oksehandelens historie. Haderslev 1978.

18. 1564 skal der have været 115 huse i byen. Landsark. Aabenraa. Top. Aabenraa amt. 1564 . Beskrivelse af Brundlund slot og Aabenraa amt.

19. Negels Becker traffer man i øvrigt i Haderslevs toldregnskab fra 1539, hvor han kom gennem Haderslev med 2 tønder hvede og senere med 2 heste. Rigsarkivet. Slesvigske og holstenske regnskaber før 1580. Rev. regnskaber. Haderslev toldregnskab. 1539.

20. Jfr. Troels Fink: Udskiftningen i Sønderjylland indtil 1770. Kbh. 1941.

21. I amtsregnskabet opgives det, at Galmansen er fra Falster, men af Haderslevs toldregnskab fra 1539 fremgår det, at han var fra Nakskov wi Lolland«. Han lagde til to gange i 1539 i havnen i Haderslev med i alt $2 \frac{1}{2}$ læst korn. I Haderslevs toldregnskab forekommer også Kersten Nansen under navnet »Christen Nanne tho Nakskow《. 
